\title{
Evaluation of the association between KIR polymorphisms and systemic sclerosis: a meta-analysis
}

\author{
Elham Karimizadeh', Shayan Mostafaei ${ }^{2}$, Saeed Aslani' ${ }^{1}$ Farhad Gharibdoost ${ }^{1}$, Ricardo Machado Xavier ${ }^{3}$, \\ Patricia Hartstein Salim ${ }^{3}$, Hoda Kavosi ${ }^{1}$, Elham Farhadi ${ }^{1,4^{*}}$ and Mahdi Mahmoudi ${ }^{1,4^{*}}$
}

\begin{abstract}
Background: The results of investigations on the association between killer cell immunoglobulin-like receptor (KIR) gene polymorphisms and the risk of systemic sclerosis (SSc) are inconsistent. To comprehensively evaluate the influence of KIR polymorphisms on the risk of SSc, this meta-analysis was performed.

Methods: A systematic literature search was performed in electronic databases including Scopus and PubMed/ MEDLINE to find all available studies involving KIR gene family polymorphisms and SSc risk prior to July 2019. Pooled odds ratios (ORs) and their corresponding 95\% confidence intervals (Cls) were measured to detect associations between KIR gene family polymorphisms and SSc risk.
\end{abstract}

Results: Five articles, comprising 571 patients and 796 healthy participants, evaluating the KIR gene family polymorphisms were included in the final meta-analysis according to the inclusion and exclusion criteria, and 16 KIR genes were assessed. None of the KIR genes were significantly associated with the risk of SSc.

Conclusions: The current meta-analysis provides evidence that KIR genes might not be potential risk factors for SSc risk.

Keywords: Killer immunoglobulin-like receptors, Systemic sclerosis, Polymorphism, Meta-analysis

\section{Introduction}

Systemic sclerosis (SSc) is a multisystem connective tissue disorder characterized by aberrant immune system activation, vascular abnormalities, inflammatory, and excessive extracellular matrix production, which results in skin and organ fibrosis [1].

Although the pathogenesis of SSc remains obscure, it is generally accepted that the complicated interplay between environmental agents and genetic predisposing factors can lead to the initiate autoimmune responses. Dysregulation of the innate immune system has been detected in autoimmune diseases such as SSc [2]. Natural killer (NK) cells are essential components of innate immune system that contribute to the early host defense. NK cells recognize cancerous and infected host cells through killer cell immunoglobulin-like receptor (KIR)-

\footnotetext{
* Correspondence: farhadie@tums.ac.ir; mahmoudim@tums.ac.ir ${ }^{1}$ Rheumatology Research Center, Tehran University of Medical Sciences, Shariati Hospital, Kargar Ave, Tehran, Iran

Full list of author information is available at the end of the article
}

major histocompatibility complex (MHC) interactions and lyse them without antigen sensitization. In addition, NK cells produce various cytokines, including interferon (IFN)- $\gamma$, tumor necrosis factor (TNF)- $\alpha$, granulocytemacrophage colony stimulating factor, interleukin (IL)-5, IL-10, IL-13, and transforming growth factor (TGF)- $\beta$ $[3,4]$. TGF- $\beta$ is defined as a profibrotic cytokine that provokes fibroblasts differentiation into myofibroblasts. Myofibroblasts are believed to be of major effector cells involved in SSc fibrosis $[5,6]$.

As mentioned above, genetic predisposition is associated with the onset and progression of SSc [7]. Studies have shown that the polymorphisms of genes, including human leukocyte antigen (HLA) [8], signal transducer and activator of transcription 4 (STAT4) [9], B cell scaffold protein with ankyrin repeats 1 (BANK1) [10], protein tyrosine phosphatase, non-receptor type 22 (PTPN22) [11], TNF alpha-induced protein 3 (TNFAIP3) [12], methyl-Cp G binding protein 2 (MECP2) [13], interleukin 1 receptor-associated kinase 1 (IRAK1) [14], and killer

(c) The Author(s). 2020 Open Access This article is distributed under the terms of the Creative Commons Attribution 4.0 International License (http://creativecommons.org/licenses/by/4.0/), which permits unrestricted use, distribution, and 
immunoglobulin-like receptor (KIR) [15] increase the risk of SSc. Moreover, the first genome-wide association study (GWAS) performed in 2010 in a European ancestry population comprising 2296 SSc cases and 5171 controls disclosed the association of CD247 gene with SSc risk [16]. As well, the French SSc GWAS on 2921 SSc patients and 6963 healthy subjects unearthed the significant association of peroxisome proliferator-activated receptor gamma (PPARG) with increased disease risk [17],

KIR receptors are members of the immunoglobulin superfamily, which are expressed on the surface of NK cells and subsets of $T$ cells [18], and are encoded by genes located on human chromosome 19q13.4. Up to date, 17 highly homologous KIR genes have been identified in human, which are divided into three different kinds; activating (2DS1 - 2DS5, and 3DS1), inhibitory (2DL1 - 2DL4, 2DL5A, 2DL5B, 3DL1, 3DL2, and 3DL3), and pseudogenes (2DP1 and 3DP1) [19]. Previous studies have shown that KIR gene polymorphisms are involved in etiopathogenesis of autoimmune diseases, such as rheumatoid arthritis (RA) [20], systemic lupus erythematosus (SLE) [21, 22], multiple sclerosis (MS) [23], and etc.

The association between KIR gene polymorphisms and the risk of SSc have been evaluated by several casecontrol studies. However, low statistical power, small sample size, clinical heterogeneity, and the extent of linkage disequilibrium between genotypes are elements which could be the cause of the inconsistent results of these studies. Meta-analysis has been proposed as an efficient method, which can integrate small studies and overcome the mentioned limitations [24]. Therefore, in this study, we perform a meta-analysis to clarify the association between KIR polymorphisms and susceptibility to the SSc.

\section{Methods}

The PRISMA guidelines were exerted to prepare this article [25].

\section{Searches and data sources}

We searched databases including PubMed/MEDLINE and Scopus to find all eligible case-control studies of KIR gene family polymorphisms and SSc risk up to July 2019. Moreover, we searched for non-digitally archived literature and interviewed relevant experts and research centers to identify any gray literature. The following keywords were used to search these databases: ("KIR" or "Killer cell immunoglobulin-like receptors) AND ("systemic sclerosis" OR "scleroderma") with "OR" and "AND" and "NOT" Boolean operators in the Title/Abstract/Keywords fields. We reviewed all references to include any related studies on genotyping and polymorphisms in the KIR gene family. Only literature published in English and human population studies were included in the current meta-analysis.

\section{Inclusion and exclusion criteria}

The following criteria were considered for study inclusion in this meta-analysis: (1) case-control studies that evaluated the association of KIR gene family polymorphisms and SSc risk; and (2) studies with available KIR gene polymorphism frequencies to allow for calculation of odds ratios (ORs) with 95\% confidence interval (CIs). The exclusion criteria were (1) duplication or overlapping subjects in any studies; (2) publications that were letters, reviews, comments, or abstract only; and (3) studies with inadequate data with respect to KIR gene polymorphism frequency.

\section{Data extraction and quality assessment}

All data were extracted according to the described criteria. The following information was included: first author's last name, year of publication, and frequency of KIR genes in SSc patients and healthy controls. The Newcastle-Ottawa Scale was used for assessing methodological quality. Studies were graded as low, moderate, or high quality according to scores of $0-3,4-6$, and 7-9, respectively. Two independent investigators without knowledge of existing scores examined the selected studies based on the criteria described above to resolve any discrepancies.

\section{Statistical methods}

We used pooled ORs and corresponding 95\% CIs for $K I R$ genes to evaluate $K I R$ gene family polymorphisms and SSc risk. In order to calculate the phenotypic frequency (pf \%) in each group, the percentage of positive numbers between all samples was used. For calculating genotypic frequency (gf) among all participants, the formula gf $=1-(1-$ pf $) \frac{1}{2}$ was exerted. Cochran's Q test was used to assess heterogeneity, and the $I^{2}$ method was employed for calculating the variation in the pooled estimations. For the latter test, significance was considered at $P<0.1$ [26]. The meta-analysis was performed with a random-effects model when heterogeneity between the individual studies was statistically significant. Otherwise, a fixed-effects model was used. Meanwhile, a sensitivity analysis was done by successively removing a particular study or group of studies (if any) that had the highest impact on the heterogeneity test. A funnel plot was established for checking the existence of publication bias. The funnel plot asymmetry was measured by Egger's linear regression test and Begg's test $(P<0.05$ was considered to indicate statistically significant publication bias) [27]. All statistical analyses were conducted by using data analysis and statistical software (STATA) 


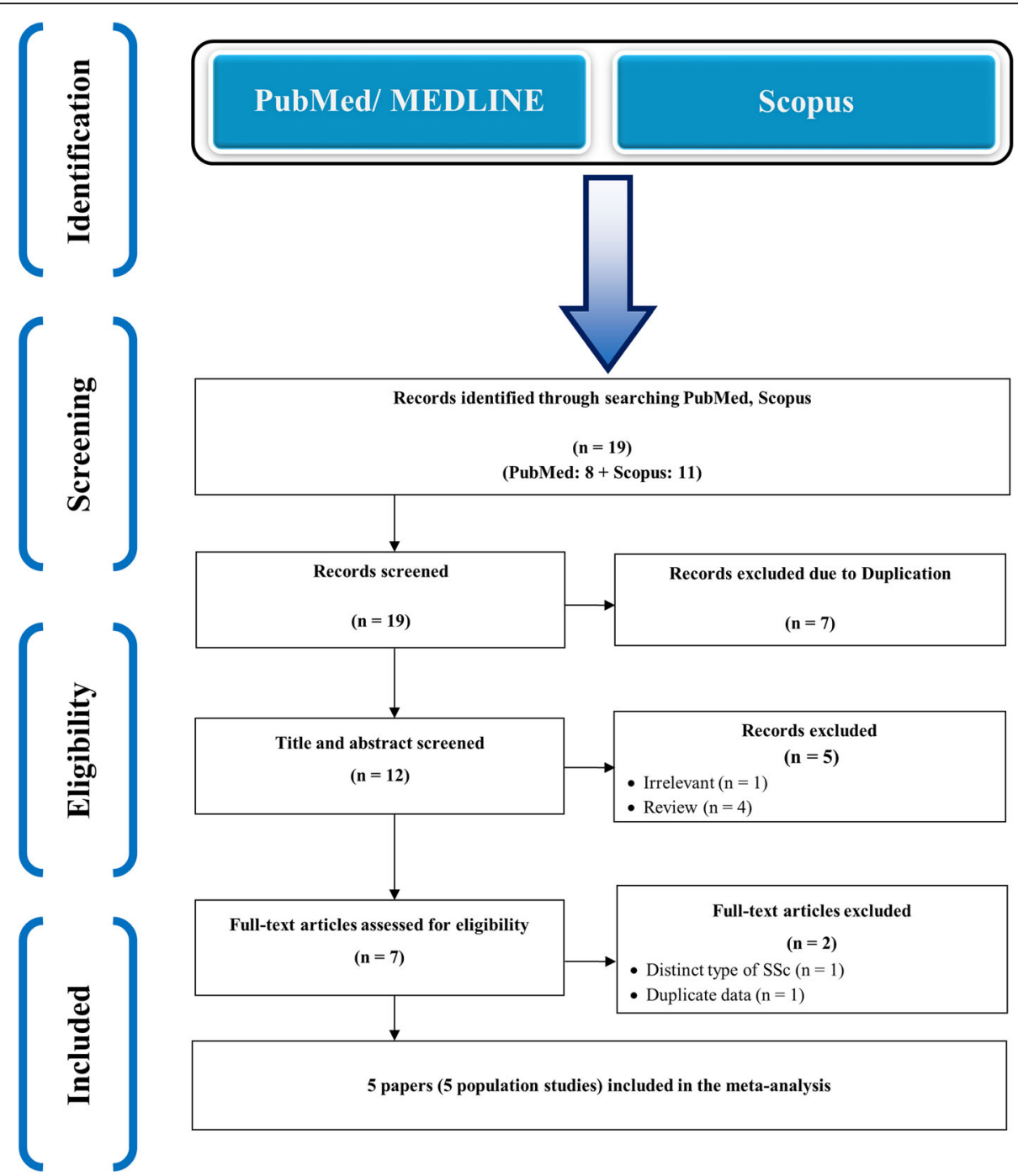

Fig. 1 Flow chart of specifications and procedure for the literature search and study selection

Table 1 Specifications of the included studies in this meta-analysis

\begin{tabular}{|c|c|c|c|c|c|c|}
\hline \multirow[t]{2}{*}{ Author (Ref) } & \multirow[t]{2}{*}{$\begin{array}{l}\text { Published } \\
\text { Year }\end{array}$} & \multirow[t]{2}{*}{$\begin{array}{l}\text { Country/ } \\
\text { Race }\end{array}$} & \multirow[t]{2}{*}{$\begin{array}{l}\text { Detection } \\
\text { Technique }\end{array}$} & $\begin{array}{l}\text { SSC } \\
\text { Patients }\end{array}$ & Controls & \multirow[t]{2}{*}{ KIR Polymorphisms } \\
\hline & & & & $\mathrm{N}$ & $\mathrm{N}$ & \\
\hline T. Momot [1] & 2004 & $\begin{array}{l}\text { Germany/ } \\
\text { Caucasian }\end{array}$ & PCR & 102 & 100 & 2DL1, 2DL2, 2DL3, 2DS1, 2DS2, 2DS3, 2DS4, 3DS1, 3DL1 \\
\hline P. H. Salim [2] & 2013 & $\begin{array}{l}\text { Brazilian/ } \\
\text { Caucasian }\end{array}$ & PCR & 115 & 115 & $\begin{array}{l}\text { 2DL1, 2DL2, 2DL3, 2DL4, 2DL5, 2DS1,2DS2, 2DS3, 2DS4, 2DS5, } \\
\text { 3DL1, 3DL2, 3DL3, 3DS1, 2DP1 }\end{array}$ \\
\hline JD. Tozkır [3] & 2016 & $\begin{array}{l}\text { Turkey/ } \\
\text { Edirne }\end{array}$ & PCR-SSP & 25 & 40 & $\begin{array}{l}\text { 2DL1, 2DL2, 2DL3, 2DL4, 2DL5, 2DL5A, 2DL5B, 2DS1, 2DS2, 2DS3, } \\
\text { 2DS4, 2DS5, 3DL1, 3DL2, 3DL3, 3DS1, 2DP1, 3DP1 }\end{array}$ \\
\hline M. Mahmoudi [4] & 2017 & $\begin{array}{l}\text { Iranian/ } \\
\text { Caucasian }\end{array}$ & PCR-SSP & 279 & 451 & $\begin{array}{l}\text { 2DL1, 2DL2, 2DL3, 2DL4, 2DL5, 2DL5A, 2DL5B, 3DL1, 3DL2, 3DL3, } \\
\text { 2DS1, 2DS2, 2DS3, 2DS4, 2DS4 (full), 2DS4 (var), 2DS5, 3DS1, 2DP1, } \\
\text { 3DP1, 3DP1 (full), 3DP1 (var) }\end{array}$ \\
\hline AC. Machado-Sulbaran [5] & 2019 & Mexico & PCR-SSP & 50 & 90 & $\begin{array}{l}\text { 2DL1, 2DL2, 2DL3, 2DL4, 2DL5, 2DS1, 2DS2, 2DS3, 2DS4, 2DS5, } \\
\text { 3DL1, 3DL2, 3DL3, 3DS1, 2DP1, 3DP1 }\end{array}$ \\
\hline
\end{tabular}




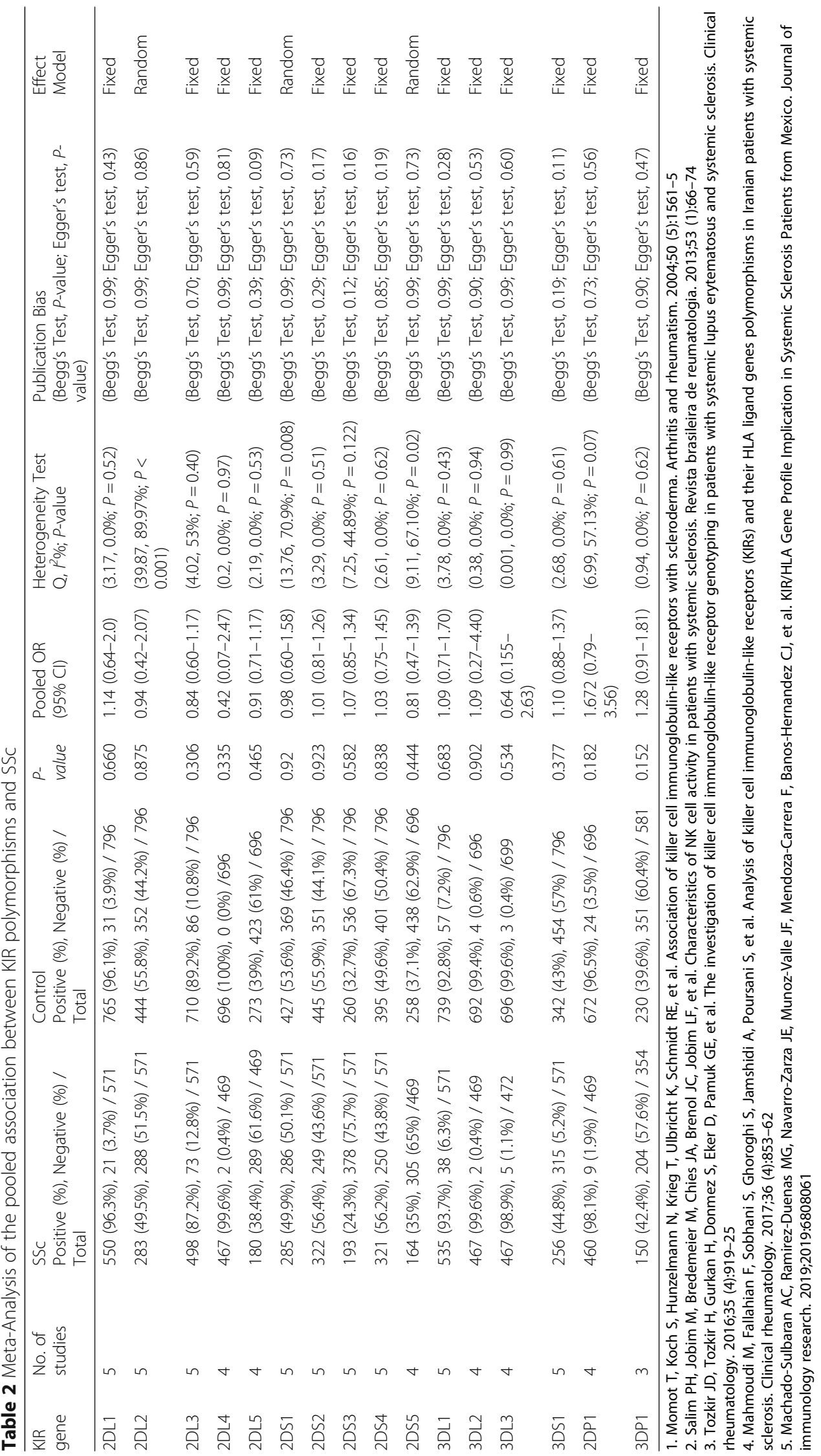


(version 11.0; Stata Corporation, College Station, TX) and MedCalc.

\section{Results}

\section{Characteristics of the eligible studies}

Figure 1 displays the inclusion/exclusion process of the potential studies with respect to the meta-analysis of KIR gene association with the risk of SSc. The initial search resulted in 19 related studies. Based on exclusion/inclusion criteria, 5 articles with 571 patients and 796 healthy participants were included in the final metaanalysis [15, 28-31]. All included papers were casecontrol studies. One paper involved the Brazilian population, and the other four studies were conducted in Europe/Germany, Turkey, Mexico, and Iran. The range of publication years was 2004 to 2019 (Table 1). Based on the Newcastle-Ottawa Scale criteria, all included studies had a total score ranging from 7 to 9 . The key characteristics and the KIR gene frequencies of the included studies in this meta-analysis are presented in Table 1.

\section{Main results and sensitivity analysis}

Table 2 presents a summary of the frequency of 16 KIR genes, pooled ORs, and heterogeneity tests of the association between the KIR polymorphisms and susceptibility to SSc. The overall analysis did not show statistically significant association of $K I R$ genes with SSc susceptibility. As examples, the forest plots of KIR2DP1 (A) and KIR3DL1 genes (B) are shown in Fig. 2.

\section{Sensitivity analysis}

A sensitivity analysis was performed by sequential omission of individual and groups of studies. The pooled ORs did not deviate with the sequential omission of any participants or group of studies, indicating that our results were statistically robust (Fig. 3).

\section{Heterogeneity and publication bias}

Heterogeneity between studies was observed for the KIR2DL3 (I2 $=53 \% ; P=0.40$ ) gene, while other $K I R$ genes did not indicate any heterogeneity. Accordingly, the random- and fixed-effects models were applied to pool the result.

Publication bias was examined by using a funnel plot and Egger's and Begg's tests. No publication bias was identified (Table 2, Fig. 4).

\section{Discussion}

SSc is a multifactorial and systemic autoimmunity disorder that can lead to fibrosis and disturbance of regular organs function [32]. SSc has a strong dependency on both genetic and environment [33]. The multiplicity of genetic factors, environmental triggers, and their interactions involved in the development of SSc disease make its pathogenesis difficult to identify.

Up to now, several genes have been identified that may influence the risk of SSc development. HLA gene family is the most generally associated gene with SSc disease. An interaction between HLA molecules and KIR receptors on NK cells can mediate the recognition and elimination of defective and foreign cells [34]. Cytotoxic activity of NK cells and certain T cells are regulated with activating and inhibitory KIRs. Preceding studies revealed that the number of NK cells have been increased in the blood of SSc patients [35]. Moreover, T and NK cells phenotype and functional abnormalities were observed in SSc patients, suggesting that these cells may play a main role in the SSc pathogenesis [36-38].

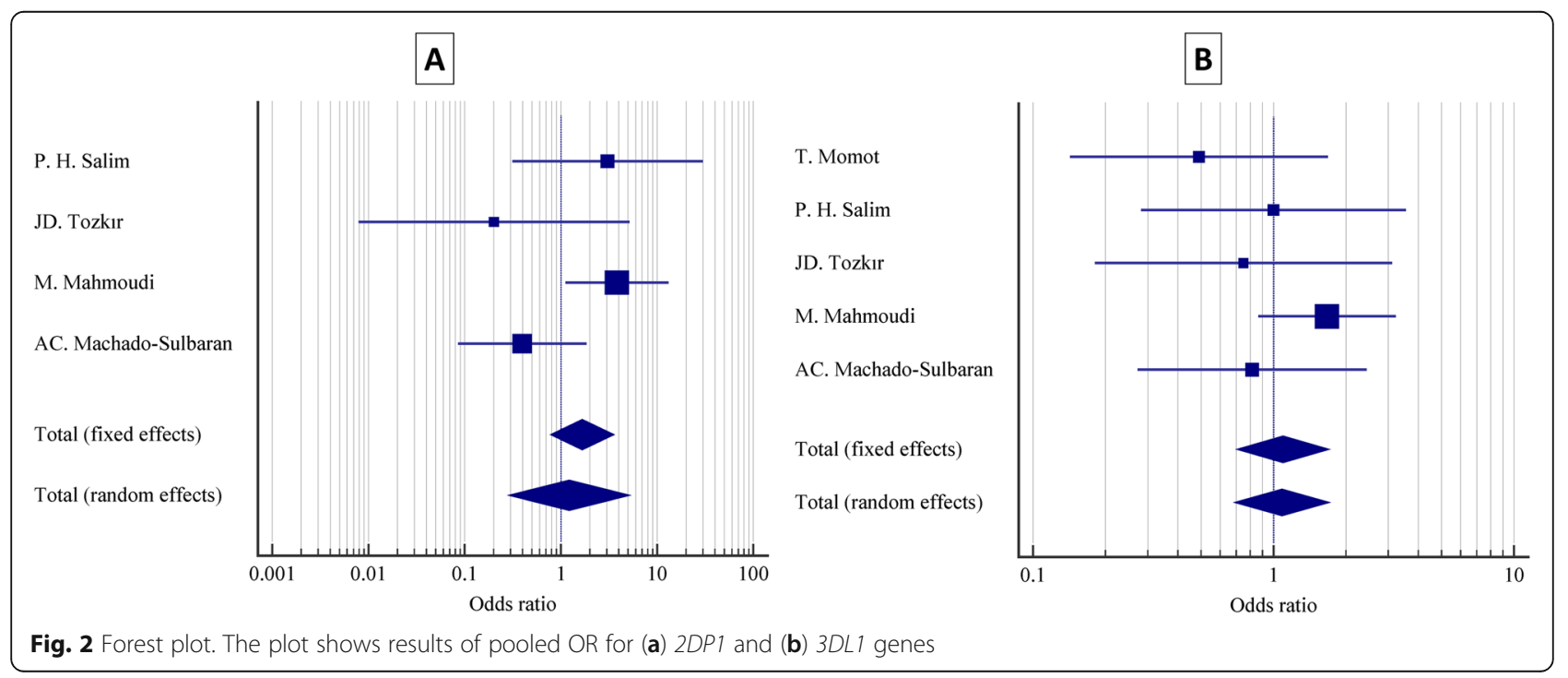




\section{A}

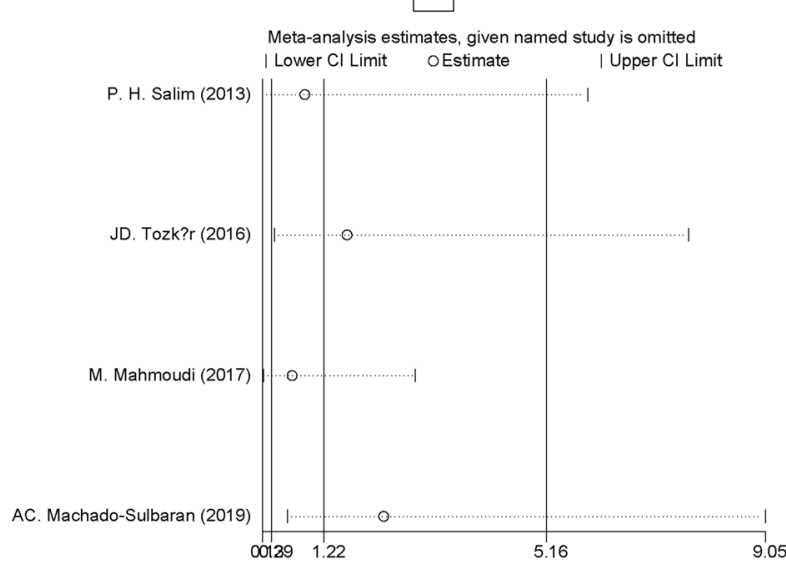

B

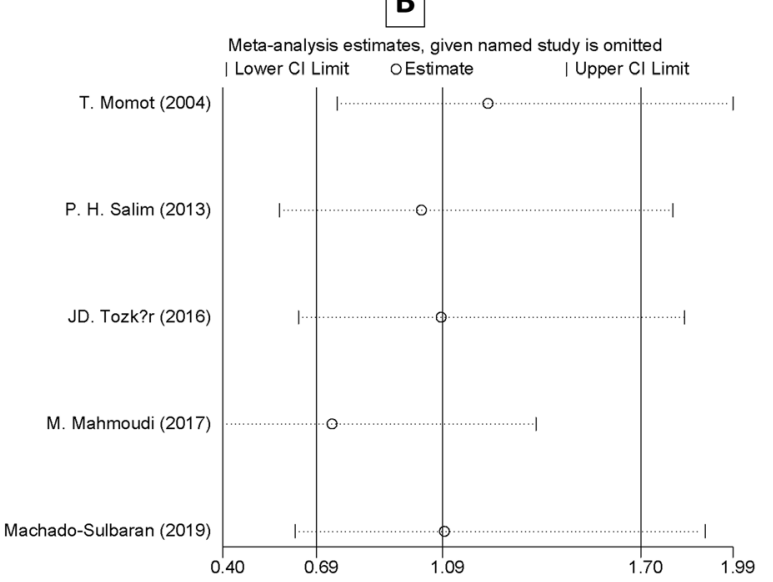

Fig. 3 Influence plot. The graph presents sensitivity analysis for (a) 2DP1 and (b) 3DL1 genes

There is a balance between inhibitory and activating KIRs in healthy individuals. The imbalance between activating and inhibitory $K I R$ genes might influence the pathogenesis of SSc through upregulation of activation or downregulation of inhibition, or a combination of both [15].

Some investigations have been performed with regard to the KIR genes polymorphisms and SSc disease in populations. For instance, Momot et al. reported that the combination of KIR2DS2 $2^{+} / K I R 2 D L 2^{-}$was associated with the risk of SSc disease [28]. The results of a study by Salim and colleagues also demonstrated the same results. In addition, they suggested that $K I R 2 D L 2^{+}$might be a potential protective factor for SSc [39]. Likewise, an investigation showed that the frequency of KIR2DS3 gene polymorphism in SSc patients was more than healthy controls [30]. In another study, Mahmoudi et al. demonstrated that none of the single KIR genes affected the risk of SSc. Moreover, they reported that the combination of KIR3DL1 with $H L A$ ligands can be a powerful marker for diagnosing of SSc [15].

As mentioned above, findings of the studies evaluating the association between KIR gene polymorphisms and the risk of SSc disease in populations are controversial. Consequently, the present meta-analysis was accomplished to quantitatively assess the relevance of $K I R$ polymorphisms with susceptibility to SSc. In this meta-analysis, the results of five case-control studies with a total of 571 SSc cases and 796 healthy controls were integrated and evaluated. Contrary to what has been observed in previous association studies, no significant association was observed between KIR genes and the risk of SSc.

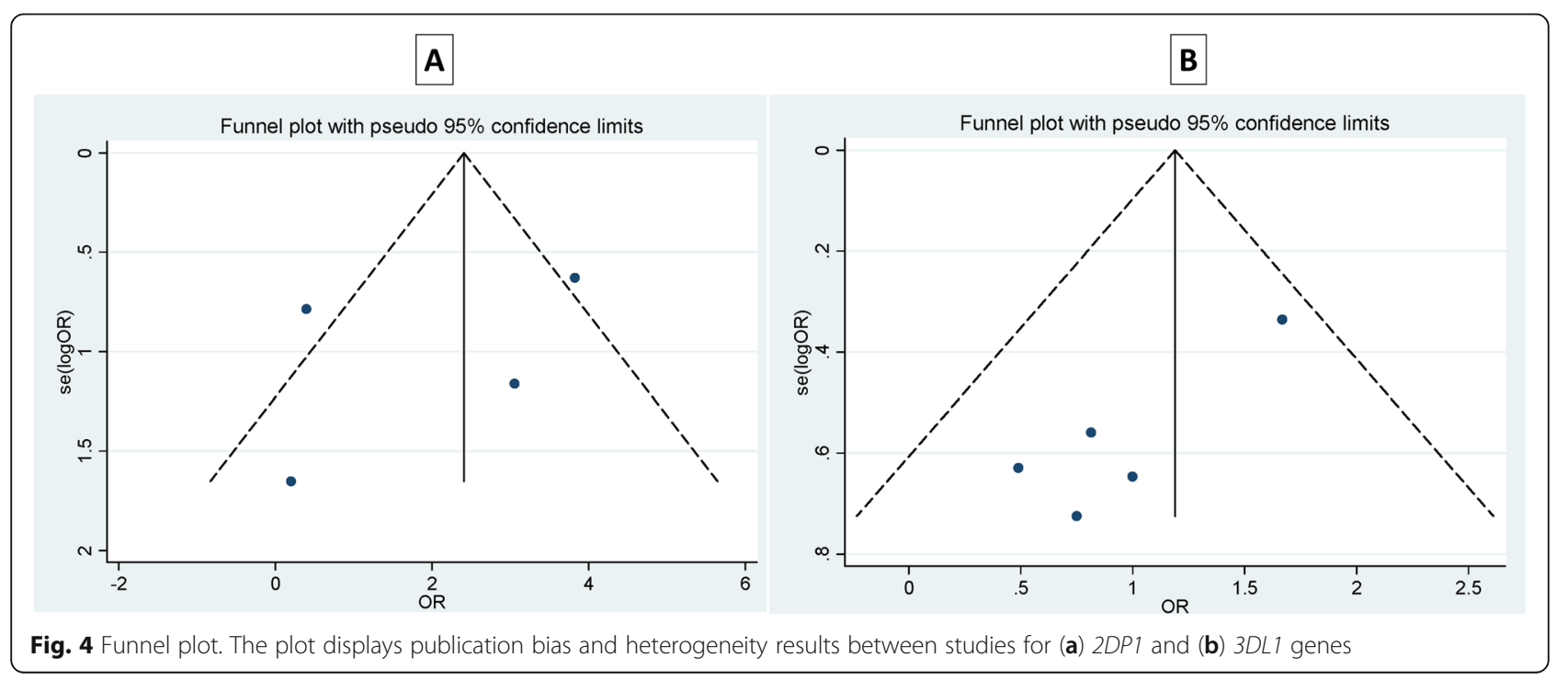


There are a number of limitations in the present meta-analysis. First, we could not perform further subgroup analysis with respect to ethnicity because of insufficient studies. Third, the meta-analysis was performed based on the data of a limited 5 studies. Therefore, this meta-analysis may have publication bias. In spite of mentioned limitations, this is the first meta-analysis focusing on the correlation between KIR genes polymorphisms and susceptibility to SSc.

\section{Conclusion}

In conclusion, this was the first meta-analysis of $K I R$ genes in association with SSc. It was detected that KIR genes are not involved in conferring a susceptibility risk to SSc development.

\section{Abbreviations}

Cl: Confidence interval; IFN: Interferon; IL: Interleukin; KIR: Killer cell immunoglobulin-like receptor; MHC: Major histocompatibility complex; MS: Multiple sclerosis; NK: Natural killer; OR: Odds ratios; RA: Rheumatoid arthritis; SLE: Systemic lupus erythematosus; SSc: Systemic sclerosis: TGF: Transforming growth factor; TNF: Tumor necrosis factor

\section{Acknowledgements}

Not applicable.

\section{Authors' contributions}

EK; Performed literature search and prepared the draft of the paper. SM; Participated in manuscript preparation and draw the figures. SA; Participated in manuscript preparation and designed the Table. FG; Developed the main idea and read the manuscript critically. RMX; Read the manuscript critically. PHS; Read the manuscript critically. HK; Participated in manuscript preparation and designed the work. EF; Developed the main idea, designed the work, and read the manuscript critically. MM; Developed the main idea designed the work, and read the manuscript critically. All authors read and approved the final manuscript

\section{Funding}

This study was supported by a grant from Deputy of Research, Tehran University of Medical Sciences (Grant No. 98-01-41-42044).

\section{Availability of data and materials}

The datasets used and/or analyzed during the current study are available from the corresponding author on reasonable request.

\section{Ethics approval and consent to participate}

Not applicable.

\section{Consent for publication}

Not applicable.

\section{Competing interests}

The authors declare that they have no competing interests.

\section{Author details}

${ }^{1}$ Rheumatology Research Center, Tehran University of Medical Sciences, Shariati Hospital, Kargar Ave, Tehran, Iran. ${ }^{2}$ Medical Biology Research Center, Health Technology Institute, Kermanshah University of Medical Sciences, Kermanshah, Iran. ${ }^{3}$ Universidade Federal do Rio Grande do Sul, Serviço de Reumatologia, Hospital de Clínicas de Porto Alegre, Porto Alegre, Brazil. ${ }^{4}$ Inflammation Research Center, Tehran University of Medical Sciences, Tehran, Iran.
Received: 18 November 2018 Accepted: 23 December 2019

Published online: 10 January 2020

\section{References}

1. Allanore $Y$, Simms R, Distler O, Trojanowska M, Pope J, Denton CP, et al. Systemic sclerosis. Nat Rev Dis Primers. 2015;1:15002.

2. Dowson C, Simpson N, Duffy L, O'Reilly S. Innate immunity in systemic sclerosis. Curr Rheumatol Rep. 2017;19(1):2.

3. Shi FD, Ljunggren HG, Sarvetnick N. Innate immunity and autoimmunity: from self-protection to self-destruction. Trends Immunol. 2001;22(2):97-101.

4. Biron CA, Nguyen KB, Pien GC, Cousens LP, Salazar-Mather TP. Natural killer cells in antiviral defense: function and regulation by innate cytokines. Annu Rev Immunol. 1999:17:189-220.

5. Karimizadeh E, Motamed N, Mahmoudi M, Jafarinejad-Farsangi S, Jamshidi A, Faridani $\mathrm{H}$, et al. Attenuation of fibrosis with selective inhibition of $\mathrm{c}-\mathrm{Ab}$ by siRNA in systemic sclerosis dermal fibroblasts. Arch Dermatol Res. 2015; 307(2):135-42

6. Gyorfi AH, Matei AE, Distler JHW. Targeting TGF-beta signaling for the treatment of fibrosis. Matrix Biol. 2018:68-69:8-27.

7. Costenbader KH, Gay S, Alarcon-Riquelme ME, laccarino L, Doria A. Genes, epigenetic regulation and environmental factors: which is the most relevant in developing autoimmune diseases? Autoimmun Rev. 2012:11(8):604-9.

8. Mayes MD, Bossini-Castillo L, Gorlova O, Martin JE, Zhou X, Chen WV, et al. Immunochip analysis identifies multiple susceptibility loci for systemic sclerosis. Am J Hum Genet. 2014;94(1):47-61.

9. Dieude P, Guedj M, Wipff J, Ruiz B, Hachulla E, Diot E, et al. STAT4 is a genetic risk factor for systemic sclerosis having additive effects with IRF5 on disease susceptibility and related pulmonary fibrosis. Arthritis Rheum. 2009; 60(8):2472-9.

10. Dieude P, Wipff J, Guedj M, Ruiz B, Melchers I, Hachulla E, et al. BANK1 is a genetic risk factor for diffuse cutaneous systemic sclerosis and has additive effects with IRF5 and STAT4. Arthritis Rheum. 2009;60(11):3447-54.

11. Diaz-Gallo LM, Gourh P, Broen J, Simeon C, Fonollosa V, Ortego-Centeno N, et al. Analysis of the influence of PTPN22 gene polymorphisms in systemic sclerosis. Ann Rheum Dis. 2011:70(3):454-62.

12. Koumakis E, Giraud M, Dieude P, Cohignac V, Cuomo G, Airo P, et al. Brief report: candidate gene study in systemic sclerosis identifies a rare and functional variant of the TNFAIP3 locus as a risk factor for polyautoimmunity. Arthritis Rheum. 2012;64(8):2746-52.

13. Carmona FD, Cenit MC, Diaz-Gallo LM, Broen JC, Simeon CP, Carreira PE, et al. New insight on the Xq28 association with systemic sclerosis. Ann Rheum Dis. 2013:72(12):2032-8.

14. Dieude P, Bouaziz M, Guedj M, Riemekasten G, Airo P, Muller M, et al. Evidence of the contribution of the $X$ chromosome to systemic sclerosis susceptibility: association with the functional IRAK1 196Phe/532Ser haplotype. Arthritis Rheum. 2011:63(12):3979-87.

15. Mahmoudi M, Fallahian F, Sobhani S, Ghoroghi S, Jamshidi A, Poursani S, et al. Analysis of killer cell immunoglobulin-like receptors (KIRs) and their HLA ligand genes polymorphisms in Iranian patients with systemic sclerosis. Clin Rheumatol. 2017:36(4):853-62.

16. Radstake TR, Gorlova O, Rueda B, Martin JE, Alizadeh BZ, Palomino-Morales $\mathrm{R}$, et al. Genome-wide association study of systemic sclerosis identifies CD247 as a new susceptibility locus. Nat Genet. 2010;42(5):426-9.

17. Lopez-Isac E, Bossini-Castillo L, Simeon CP, Equrbide MV, Alegre-Sancho JJ, Callejas $\mathrm{J}$, et al. A genome-wide association study follow-up suggests a possible role for PPARG in systemic sclerosis susceptibility. Arthritis Res Ther. 2014;16(1):R6.

18. Salim PH, Jobim M, Jobim LF, Xavier RM. Autoimmune rheumatic diseases and their association with killer immunoglobulin-like receptor genes. Rev Bras Reumatol. 2011;51(4):351-6 62-4.

19. Parham P. Immunogenetics of killer cell immunoglobulin-like receptors. Mol Immunol. 2005;42(4):459-62

20. Fogel LA, Yokoyama WM, French AR. Natural killer cells in human autoimmune disorders. Arthritis Res Ther. 2013:15(4):216.

21. Pellett F, Siannis F, Vukin I, Lee P, Urowitz MB, Gladman DD. KIRs and autoimmune disease: studies in systemic lupus erythematosus and scleroderma. Tissue Antigens. 2007;69(Suppl 1):106-8.

22. Liang $\mathrm{HL}, \mathrm{Ma} \mathrm{SJ}$, Tan HZ. Association between killer cell immunoglobulinlike receptor (KIR) polymorphisms and systemic lupus erythematosus (SLE) in populations: a PRISMA-compliant meta-analysis. Medicine (Baltimore). 2017;96(10):e6166 
23. Fusco C, Guerini FR, Nocera G, Ventrella G, Caputo D, Valentino MA, et al. KIRs and their HLA ligands in remitting-relapsing multiple sclerosis. J Neuroimmunol. 2010;229(1-2):232-7.

24. Lohmueller KE, Pearce CL, Pike M, Lander ES, Hirschhorn JN. Meta-analysis of genetic association studies supports a contribution of common variants to susceptibility to common disease. Nat Genet. 2003;33(2):177-82.

25. Moher D, Shamseer L, Clarke M, Ghersi D, Liberati A, Petticrew M, et al. Preferred reporting items for systematic review and meta-analysis protocols (PRISMA-P) 2015 statement. Syst Rev. 2015;4(1):1.

26. Huedo-Medina TB, Sánchez-Meca J, Marín-Martínez F, Botella J. Assessing heterogeneity in meta-analysis: $\mathrm{Q}$ statistic or $\mathrm{I}^{2}$ index? Psychol Methods. 2006;11(2):193

27. Egger M, Smith GD, Schneider M, Minder C. Bias in meta-analysis detected by a simple, graphical test. BMJ. 1997;315(7109):629-34.

28. Momot T, Koch S, Hunzelmann N, Krieg T, Ulbricht K, Schmidt RE, et al. Association of killer cell immunoglobulin-like receptors with scleroderma. Arthritis Rheum. 2004;50(5):1561-5.

29. Salim PH, Jobim M, Bredemeier M, Chies JA, Brenol JC, Jobim LF, et al. Characteristics of NK cell activity in patients with systemic sclerosis. Rev Bras Reumatol. 2013;53(1):66-74.

30. Tozkir JD, Tozkir H, Gurkan H, Donmez S, Eker D, Pamuk GE, et al. The investigation of killer cell immunoglobulin-like receptor genotyping in patients with systemic lupus erytematosus and systemic sclerosis. Clin Rheumatol. 2016;35(4):919-25.

31. Machado-Sulbaran AC, Ramirez-Duenas MG, Navarro-Zarza JE, Munoz-Valle JF, Mendoza-Carrera F, Banos-Hernandez CJ, et al. KIR/HLA gene profile implication in systemic sclerosis patients from Mexico. J Immunol Res. 2019; 2019:6808061.

32. van den Hoogen F, Khanna D, Fransen J, Johnson SR, Baron M, Tyndall A, et al. 2013 classification criteria for systemic sclerosis: an American College of Rheumatology/European league against rheumatism collaborative initiative. Arthritis Rheum. 2013;65(11):2737-47.

33. Tan FK. Systemic sclerosis: the susceptible host (genetics and environment). Rheum Dis Clin N Am. 2003;29(2):211-37.

34. Rajagopalan S, Long EO. Understanding how combinations of HLA and KIR genes influence disease. J Exp Med. 2005;201(7):1025-9.

35. Puxeddu I, Bongiorni F, Chimenti D, Bombardieri S, Moretta A, Bottino C, et al. Cell surface expression of activating receptors and co-receptors on peripheral blood NK cells in systemic autoimmune diseases. Scand J Rheumatol. 2012;41(4):298-304.

36. Almeida I, Silva SV, Fonseca AR, Silva I, Vasconcelos C, Lima M. T and NK cell phenotypic abnormalities in systemic sclerosis: a cohort study and a comprehensive literature review. Clin Rev Allergy Immunol. 2015;49(3):347-69.

37. Benyamine A, Magalon J, Sabatier F, Lyonnet L, Robert S, Dumoulin C, et al. Natural killer cells exhibit a peculiar phenotypic profile in systemic sclerosis and are potent inducers of endothelial microparticles release. Front Immunol. 2018;9:1665.

38. Horikawa M, Hasegawa M, Komura K, Hayakawa I, Yanaba K, Matsushita T, et al. Abnormal natural killer cell function in systemic sclerosis: altered cytokine production and defective killing activity. J Invest Dermatol. 2005; 125(4):731-7.

39. Salim PH, Jobim M, Bredemeier M, Chies JA, Schlottfeldt J, Brenol JC, et al. Killer cell immunoglobulin-like receptor (KIR) genes in systemic sclerosis. Clin Exp Immunol. 2010;160(3):325-30.

\section{Publisher's Note}

Springer Nature remains neutral with regard to jurisdictional claims in published maps and institutional affiliations.

Ready to submit your research? Choose BMC and benefit from:

- fast, convenient online submission

- thorough peer review by experienced researchers in your field

- rapid publication on acceptance

- support for research data, including large and complex data types

- gold Open Access which fosters wider collaboration and increased citations

- maximum visibility for your research: over $100 \mathrm{M}$ website views per year

At BMC, research is always in progress.

Learn more biomedcentral.com/submissions 